\title{
HUKUM LAHAN
}

\author{
Muh. Akbar \\ Jurusan Perbankan Syariah Ekonomi Dan Bisnis Islam \\ Universitas Islam Negeri Alauddin Makassar
}

Muha63672@gmail.com

\begin{abstract}
Abstrak
Penulisan ini bertujuan untuk mengkaji politik hukum berupa arah kebijakan yang melatarbelakangi lahirnya berbagai regulasi pengelolaan lahan gambut di Indonesia. Beberapa catatan yang penulis termukan bahwa politik hukum pengaturan pengelolaan lahan gambut sangat bervariasi dan sudah mengarah kepada pembangunan berkelanjutan. Sedangkan pengaturan terkait pengelolaan lahan gambut masih terdapat inkonsistensi terhadap UU 32/2009. Inkosistensi tersebut meliputi aspek: 1) Perencanaan; 2) Pengendalian; 3) Pemeliharaan; dan (4) Sanksi Administratif. Tulisan ini menggunakan metode penelitian normatif dengan pendekatan peraturan perundang-undangan(statute approach) dan pendekatan historis (historical approach).
\end{abstract}

Kata Kunci : Politik hukum; Pengelolaan lahan gambut; Kebijakan gambu 
Sektor kehutanan menjadi penting dalam soal perubahan iklim karena ia menjadi penyumbang terbesar emisi dari Indonesia (kebanyakan dari kebakaran hutan dan pembukaan hutan - apalagi jika lahannya gambut). Dengan menurunkan emisi dari sektor kehutanan, maka Indonesia mempunyai peluang besar untuk menurunkan emisi sebanyak $26 \%$ di tahun 2020. Pengaturan mengenai. perlindungan dan pengelolaan lahan gambut telah diatur di dalam berbagai produk hukum mulai dari Undang-Undang/UU, Peraturan Pemerintah/PP, Peraturan Presiden/Perpres, dan Peraturan Menteri/Permen. Apabila dirunut, kebijakan yang pertama kali dikeluarkan oleh Pemerintah terkait gambut adalah Keputusan Presiden No. 32 Tahun 1990 tentang Pengelolaan Kawasan Lindung yang menyebutkan kawasan gambut dan kriterianya sebagai salah satu bagian dari kawasan yang memberikan perlindungan di bawahnya. Secara umum Keppres tersebut dilatarbelakangi semakin terbatasnya ruang untuk menyelenggarakan kehidupan dan pembangunan yang berkelanjutan, sehingga diperlukan pengaturan untuk mencegah timbulnya kerusakan fungsi lingkungan hidup.

Berbagai peristiwa kebakaran hutan di lahan gambut dan forum internasional mengenai gambut memunculkan respon kebijakan. Dalam kurun waktu sejak 1982 hingga 2017 telah terjadi beberapa kali kebakaran hutan di mana pada tahun 2015 yang dianggap sebagai kebakaran hutan di lahan gambut terbesar dan mendapat respon pemerintah dengan mengeluarkan kebijakan (regulasi) mulai dari peraturan pemerintah hingga peraturan menteri. Sedangkan di tataran internasional, COP (Conference of the Parties to the UNFCCC) merupakan otoritas tertinggi dalam upaya global penanganan dan pengendalian perubahan iklim di bawah Perserikatan Bangsa-bangsa (PBB). COP telah diselenggarakan sejak tahun 1995 di Berlin setelah UNFCCC berkekuatan hukum pada tahun 1994.4Sebagaimana diketahui, UNFCCC merupakan payung internasional yang diterjemahkan implementasinya melalui Protokol Kyoto (yang diadopsi pada 1997 dan berkekuatan hukum pada 2005) serta Persetujuan Paris (yang diadopsi pada 2015dan berkekuatan hukum pada 2016).5 Berikut tabel kronologis respon kebijakan pengelolaan lahan gambut sejak tahun 1982 hingga 2017. (Maryam, 2018)

Hal ini sekali lagi secara tidak langsung menunjukkan bahwa lahan gambut memiliki aspek yang sangat penting dalam keberlangsungan lingkungan hidup yang perlu kiranya diatur dalam peraturan perundang-undangan yang lebih tinggi dan khusus mengatur tentang batasan pengelolaan dan pengunaannya. 
Sebagai respon untuk mempercepat pemulihan gambut rusak akibat kebakaran, Presiden mengeluarkan Peraturan Presiden Nomor 1 Tahun 2016 tentang Badan Restorasi Gambut.

Upaya pemerintah untuk mewujudkan ketahanan pangan terancam seiring dengan maraknya alih fungsi lahan pertanian pangan untuk non pertanian pangan. Berdasarkan data BPS, hingga tahun 2003 rata-rata alih fungsi lahan sawah sebesar 187.197,7 hektar per tahun.1 Selanjutnya pada tahun 2017, data BPS menunjukkan luas sawah yang semula 7,75 juta hektar, turun pada tahun 2018 menjadi 7,1 juta hektar.2 Banyaknya alih fungsi lahan pertanian pangan juga dikemukakan oleh Menteri Agraria dan Tata Ruang, Sofyan Djalil bahwa setiap tahun terjadi alih fungsi lahan sawah sebanyak 150.000 hingga 200.000 hektar. Alih fungsi lahan pertanian pangan tersebut digunakan untuk kepentingan industri, perumahan, dan sebagainya. Jumlah alih fungsi lahan pertanian pangan tersebut meningkat hingga $100 \%$ jika dibandingkan tahun 2011, dimana alih fungsi lahan sawah menjadi non sawah pada waktu itu hanya sekitar 100.000 hektar per tahun. Pada tahun 2017, lahan sawah bahkan turun 413.727 hektar jika dibandingkan tahun 2016. Pada tahun 2016, luas lahan sawah 5,24 juta hektar, namun pada tahun 2017 menjadi 4,82 juta hektar. (Cahyaningrum, 2019)

Alih fungsi lahan pertanian pangan terjadi hampir di seluruh wilayah Indonesia, antara lain di Kabupaten Karawang, Jawa Barat dan Kabupaten Tabanan, Bali. Di Karawang, lahan pertanian pangan terancam seiring dengan peningkatan jumlah penduduk dan perkembangan Karawang sebagai salah satu kawasan strategis ekonomi yang mengakibatkan. permintaan lahan meningkat dan berdampak pada terjadinya alih fungsi lahan pertanian pangan.4 Antara 20112013, luas lahan sawah berkurang 511 hektar. Ini berarti rata-rata pengurangan lahan sawah per tahun 255,5 hektar.5 Alih fungsi lahan pertanian pangan di Karawang terus terjadi dan pada pertengahan 2016 mencapai 150 hektar per tahun.6 Selanjutnya berdasarkan data Kontak Tani Nelayan Andalan, pada tahun 2017 telah terjadi penyusutan lahan pertanian pangan di Karawang hingga 30 ribuan hektar. Pada Tahun 2016, lahan pertanian di Karawang seluas 97.000 hektar, turun menjadi 94.000 hektar pada tahun 2017.

Sementara di Kabupaten Tabanan, Bali selama 7 tahun terakhir (2011-2017) rata-rata alih fungsi lahan pertanian mencapai 53,40 hektar per tahunnya atau setara dengan 0,25 persen per tahunnya. 8 Alih fungsi lahan pertanian pangan 
tertinggi terjadi pada tahun 2015 ke tahun 2016 yaitu dari 21.662 hektar menjadi 21.784 hektar. Seperti halnya Karawang, lahan pertanian pangan di Tabanan banyak dialihkan menjadi bangunan seperti pemukiman, perkantoran, tempat usaha, jalan, dan sebagainya. (Burdatun, 2013)

Pemerintah selaku pemegang hak pen-guasaan atas bumi, air, dan kekayaan alam yang terkandung di dalamnya sebagaimana tertuang di dalam UndangUndang Dasar Negara Republik Indonesia Tahun 1945, Pasal 33 ayat (3), menentukan "bumi, air, dan kekayaan alam yang terkandung di dalamnya dikuasai oleh Negara dan dipergunakan sebesar-besarnya kemakmuran rakyat". Ketentuan ini menjadi landasan filosofis dan landasan yuridis bagi Negara Indonesia dalam rangka men-gelola sumber daya alam (SDA) sekaligus mengatur hak-hak penguasaan dan pe-manfaatan tanah, air dan ruang angkasa dengan prinsip kebersamaan, efisiensi, berkeadilan, berkelanjutan, berwawasan lingkungan. Negara Indonesia sebagai or-ganisasi kekuasaan yang tertinggi seluruh.

rakyat Indonesia, dalam hal ini pemerin-tah Indonesia sebagai pengemban utama tanggungjawab memajukan kesejahteraan umum bagi rakyat Indonesia diberikan ke-wenangan oleh UUPA sebagai pemegang kekuasaan yang tertinggi atas bumi, air dan ruang angkasa, termasuk kekayaan alam yang terkandung di dalamnya sebagaimana yang tercermin di dalam ketentuan Pasal 2 ayat (1) UUPA, bahwa bumi, air dan ruang angkasa, termasuk kekayaan alam yang terkandung di dalamnya itu, pada tingka-tan yang tertinggi "dikuasi" oleh Negara sebagai organisasi seluruh rakyat.

Hak menguasai Negara dimaksud adalah memberikan kewenangan kepada lembaga hukum dan hubungan hukum konkrit antara Negara dengan Tanah Indonesia. Kewenangan Negara tersebut merupakan pelimpahan tugas Bangsa, sehingga kewenangan tersebut semata-mata bersifat publik. Negara dalam hal ini bukan sebagai suatu badan hukum yang memiliki, akan tetapi Negara diberikan kewenangan untuk mengatur sebagaimana yang tercantum dalam Pasal 2 ayat (2) UUPA:

a.Mengatur dan menyelenggarakan peruntukkan, penggunaan, persediaan dan pemeliharaan bum, air dan ruang angkasa tersebut;

b.Menentukan dan mengatur hubungan-hubungan hukum antara orang-orang dengan bumi, air dan ruang angkasa; 
c.Mengatur dan menentukan hubungan-hubungan hukum antara orang-orang dan perbuatan-perbuatan hukum yang mengenai bumi, air dan ruang angkasa

Menggali pemahaman dan pandangan masyarakat adat Maluku tentang tanah berarti menggali pemahaman mereka tentang alam semesta. Karena masyarakat Maluku pada umumnya adalah masyarakat yang kosmik. Pemahaman tentang sesuatu di alam tidak terpisahkan dari pemahaman dan pandangan mengenai alam semesta dan manusia sebagai satu kesatuan. Pintu masuk untuk memahami konsep tanah dalam masyarakat adat Maluku yaitu pemahaman masyarakat Maluku tentang penguasa alam semesta yang dikenal dengan sebutan dalam bahasa Ambon Melayu, Upu Lanite dan Upu Tapele (Tuhan Langit dan tuhan Bumi / Tanah). Konsep Lanite dan Tapele ini masih menjadi perdebatan karena dalam tradisi masyarakat adat Maluku konsep ini tidak banyak yang ditemukan. Konsep yang banyak ditemukan di masyarakat adat Maluku adalah tentang adat dan leluhur. Karena itu tepat bagi kita untuk memahami konsep tanah dalam pandangan masyarakat adat Maluku, dari cara mereka memahami adat dan leluhur.

Perlindungan Lahan Pertanian Pangan Berkelanjutan sebagaimana diaturdalamUndang-undangNo.41Tahun2009, merupakanimplementasi dariKonstitusiNasional IndonesiaPasal20,Pasal21,Pasal27ayat(2),Pasal28A,Pasal28C, danPasal33Undang-UndangDasarNegaraRepublik IndonesiaTahun1945. Kemudiandiimp lementasilebihlanjutolehPeraturan PemerintahNo.1Tahun 2011Tentang Penetapan danAlihFungsiLahan Pertanian Pangan Berkelanjutan.Mengingatmasalahalih fungsilahan pertanian pangan,terutama lahan pertanian (sawah)ke lahan non pertanian sawahdimanasetiaptahunterjadi konversi lahan. (A.Pieter, 2013)

Sejalan dengan itu,upaya membangun ketahanan dan kedaulatan pangan untuk mewujudkan kesejahteraan rakyat adalah hal yang sangatpenting untuk direalisasikan.Dalamrangka mewujudkan ketahanan dan kedaulatan pangan perlu diselenggarakan pembangunan pertanian berkelanjutan,yang sebagian besar bidang usahanya masih bergantung pada polapertanianberbasislahan. 
Peranan sektor pertanian bagipembangunan perekonomian bangsa Indonesia masih sangatpenting dengan dasar sektor inidalammenunjang pembentukanPDB,penciptaan kesempatankerja,peningkatan pendapatan masyarakatdan perolehan devisa.Peranan sektor pertanian secara komprehensifjuga dilihatsebagaipenyediaan pangan masyarakatsehingga mampu secara strategis dalampenciptaan ketahanan pangan (foodsecurity) yangsangat eratkaitannyadenganketahanansosial (sosiosecurity),stabilitas ekonomi,politik dan keamanan atau ketahanan nasional(nationalsecurity); serta peranan dalampenyediaan jasa-jasalingkungan (Daryanto,2009) .

Dalamrevitalisasipembangunan pertanian, dikemukakan bahwa perlu penyediaan lahan basah abadiseluas 15juta ha untuk memenuhikebutuhan pangan nasional.Sementara pada saatiniluaslahan basah yangtelah dimanfaatkan,khususnya lahan basah baru sekitar 7,8 juta ha.Dilain pihak alihfungsilahansawah setiaptahunsekitar 110.000 ha dan laju pencetakan sawahyangdibiayaiPemerintahdanPemerintahDaerahsekitar40.00050.000hapertahun.Jadisecaramakroterdapatdefisitlahansawahsetiaptahunsekitar 60.000 ha.

Sektor pertanianmerupakansektor keduayang terbesar dalamproduk domestik regionalbrutodiKabupaten Gresik.Dengan posisiyangkedua ini, peranansektor pertaniantersebut menjadi penting.Dilihat dari jumlahPDRBmasing-masing subsektor,SubSektorTanaman Bahan Makanan merupakan subsektoryangtinggidengannilaiRp. 203.691,56jutapadatahun1998dan Rp.210.019,15jutapadatahun2001.Untukkomoditastanamanpangan,jenis komoditas padisawah memilikitingkatproduksiyanglebihtinggi.Nilai produksi pada sawah ini sebesar 278.602,66 ton pada tahun 1998 dan320.542,29padatahun2002.Sedangkankomoditasyangter kecil adalah kacanghijaudenganproduksi4.927,22pada tahun1998dan2.199,77pada tahun 2002.Haltersebutdidukung denganluas tanahsawahyang masih dominandi wilayahKabupatenGresik,yaitusebesar 36.387,94haatau30,64\%dariseluruhwilayahkabupatenGresik,dimanaluaslahansa wahyangpalingluasdiKecamatanBalongpanggangseluas5.066,97ha.Namun,seiri ng dengan perkembangan permukiman danindustry diKabupaten Gresik,luas lahanpertanianjugamengalami konversi lahan. (Takim, 2016) 
Pemerintah mempunyai tugas dan tanggungjawab untuk mengusahakan kesejahteraan bagi warganya. Sejak itu negara turut serta secara aktif dalam pergaulan kemasyarakatan, sehingga lapangan pekerjaan pemerintah makin lama makin luas. Administrasi negara diserahi tugas untuk menyelenggarakan kesejahteraan umum dengan cara ikut serta secara aktif dalam berbagai kehidupan rakyatnya di bidang ekonomi, sosial, budaya, medis, perpajakan dan sebagainya. Peran pemerintah dalam berbagai kegiatan masyarakat semakin nyata. Salah satu campur tangan pemerintah terhadap aktivitas masyarakat yang begitu terasa dalam hal ini adalah melalui instrumen perizinan. Melalui perizinan pemerintah mencampuri, mengarahkan, mengendalikan berbagai aktivitas dan sepak terjang warganya.

1) Ketentuan perizinan sebagaimana dimaksud dalam Pasal 52 ayat (2) huruf b merupakan acuan bagi pejabat yang berwenang dalam pemberian izin pemanfaatan ruang berdasarkan rencana tata ruang yang ditetapkan dalam Peraturan Daerah ini.

(2) Ketentuan perizinan ini bertujuan untuk:

a. Menjamin pemafaatan ruang sesuai dengan rencana tata ruang, peraturan zonasi, dan standar pelayanan minimal bidang penataan ruang;

b. Mencegah dampak negatif peman-faatan ruang; danc. Melindungi kepentingan umum.

(3) Pemberian izin pemanfaatan ruang disertai dengan persyaratan teknis dan persyaratan administratif sesuai dengan ketentuan peraturan perundangundangan;

(4) Pemerintah Daerah melimpahkan ke-wenangan dalam penerbitan izin kepada Satuan Kerja Perangkat Daerah (SKPD) Kota yang membidangi perizinan. 


\section{Undang-Undang Nomor 32 Tahun 2009 tentang Perlindungan dan Pengelolaan Lingkungan Hidup.}

\section{Bahwa sesuai Pasal 69 ayat (1):}

a. huruf a menyatakan bahwa "Setiap orang dilarang melakukan perbuatan yang mengakibatkan pencemaran dan/atau perusakan lingkungan hidup";

b. huruf h menyatakan bahwa "Setiap orang dilarang melakukan pembukaan lahan dengan cara membakar";

c. huruf $\mathrm{j}$ menyatakan bahwa "Setiap orang dilarang memberikan informasi palsu, menyesatkan, menghilangkan informasi, merusak informasi, atau memberikan keterangan yang tidak benar".

2. Bahwa sesuai Pasal 98 ayat (1) menyatakan bahwa "Setiap orang yang dengan sengaja melakukan perbuatan yang mengakibatkan dilampauinya baku mutu udara ambien, baku mutu air, baku mutu air laut, atau kriteria baku kerusakan lingkungan hidup, dipidana dengan pidana penjara paling singkat 3 (tiga) tahun dan paling lama 10 (sepuluh) tahun dan denda paling sedikit Rp3.000.000.000,00 (tiga miliar rupiah) dan paling banyak Rp10.000.000.000,00 (sepuluh miliar rupiah)".

Bahwa sesuai Pasal 108 menyatakan bahwa "Setiap orang yang melakukan pembakaran lahan sebagaimana dimaksud dalam Pasal 69 ayat (1) huruf $h$, dipidana dengan pidana penjara paling singkat 3 (tiga) tahun dan paling lama 10 (sepuluh) tahun dan denda paling sedikit Rp3.000.000.000,00 (tiga milyar rupiah) dan paling banyak Rp10.000.000.000,00 (sepuluh milyar rupiah)".

3. Bahwa sesuai Pasal 113 menyatakan bahwa "Setiap orang yang memberikan informasi palsu, menyesatkan, menghilangkan informasi, merusak informasi, atau memberikan keterangan yang tidak benar yang diperlukan dalam kaitannya dengan pengawasan dan penegakan hukum yang berkaitan dengan perlindungan dan pengelolaan lingkungan hidup sebagaimana dimaksud dalam Pasal 69 ayat (1) huruf $\mathrm{j}$ dipidana dengan pidana penjara paling lama 1 (satu) tahun dan denda paling banyak Rp1.000.000.000,00 (satu milyar rupiah)".

4. Bahwa sesuai Pasal 114 menyatakan bahwa "Setiap penanggung jawab usaha dan/atau kegiatan yang tidak melaksanakan paksaan pemerintah dipidana dengan pidana penjara paling lama 1 (satu) tahun dan denda paling banyak Rp1.000.000.000,00 (satu milyar rupiah)".

5. Bahwa sesuai Pasal 115 menyatakan bahwa "Setiap orang yang dengan sengaja mencegah, menghalang-halangi, atau menggagalkan pelaksanaan tugas 
pejabat pengawas lingkungan hidup dan/atau pejabat penyidik pegawai negeri sipil dipidana dengan pidana penjara paling lama 1 (satu) tahun dan denda paling banyak Rp500.000.000,00 (lima ratus juta rupiah)".

6. Bahwa sesuai Pasal 116 ayat (1) menyatakan bahwa "Apabila tindak pidana lingkungan hidup dilakukan oleh, untuk, atau atas nama badan usaha, tuntutan pidana dan sanksi pidana dijatuhkan pada;

a. Badan usaha; dan/ atau

b. Orang yang memberi perintah untuk melakukan tindak pidana tersebut atau orang yang bertindak sebagai pemimpin kegiatan dalam tindak pidana tersebut

7. Bahwa sesuai Pasal 116 ayat (2) menyatakan bahwa "Apabila tindak pidana lingkungan hidup sebagaimana sebagai ayat (1) dilakukan oleh orang, yang berdasarkan hubungan kerja atau berdasarkan hubungan lain yang bertindak dalam lingkup kerja badan usaha, sanksi pidana dijatuhkan terhadap pemberi perintah atau pemimpin dalam tindak pidana tersebut tanpa memperhatikan tindak pidana tersebut dilakukan secara sendiri atau bersama-sama".

8. Bahwa sesuai Pasal 119 menyatakan bahwa "Selain pidana sebagaimana dalam Undang-Undang ini, terhadap badan usaha dapat dikenakan pidana tambahan atau tindakan tata tertib berupa:

a. Perampasan keuntungan yang diperoleh dari tindak pidana;

b. Penutupan seluruh atau sebagian tempat usaha dan/atau kegiatan;

c. Perbaikan akibat tindak pidana;

d. Pewajiban mengerjakan apa yang dilalaikan tanpa hak; dan/atau

e. Penempatan perusahaan dibawah pengampuan paling lama 3 (tiga) tahun." 


\section{Daftar Pustaka}

A.Pieter, N. V. (2013). Pemahaman Hak Hak Tanah. Ekonomi Syariah, 1(2), $70-90$.

Burdatun, B. (2013). Penegakan Hukum. Ekonomi Syariah, 1(2), 50-80.

Cahyaningrum, D. (2019). Politik Hukum Pengelolaan Lahan. Ekonomi Syariah, $1(2), 80-100$.

Maryam, R. (2018). Politik Hukum perlindungan Lahan. Ekonomi Syariah, 1(2), $60-80$.

Takim, M. (2016). Perlindungan Hukum Lahan. Ekonomi Syariah, 1(2), 100120. 